\title{
Treepie Dendrocitta vagabunda parvula (Passeriformes: Corvidae) as a natural enemy of the pests of crops and fruites in District Haripur, KPK, Pakistan
}

\author{
saira bibi ${ }^{1}$, FIAZ KHAN ${ }^{1}$, and AQSA REHMAN ${ }^{1}$ \\ ${ }^{1}$ Hazara University
}

May 4, 2020

\begin{abstract}
In district Haripur, KPk, Pakistan Treepie Dendrocitta vagabunda parvula (Latham, 1790) (Passeriformes: Corvidae), is a widespread resident bird commonly found. Feeding and Food habits of Treepie were studied by direct focal observation method analysis of gut content and faecal matter. Treepie prefers tree and cultivation areas insects for foraging activities, feeding on animal and plant is an omnivore items ranging from vertebrate species to invertebrate. Feeding upon like red palm weevil, grasshopper, cockroaches, banana stem weevil, nestlings of squirrel and house rat, it feeds up on many pests of agricultural crops Treepie is an important biocontrol agent in the agro ecosystem of the region
\end{abstract}

\section{Introduction:}

In most agricultural systems Biological pest control research has traditionally overlooked the Role and importance of vertebrate predators. a high diversity of species can be supported by A landscape matrix composed of semi-natural habitats and agriculture (Altieri, 1999), however, environmental degradation and agricultural increase pose a major threat to the composition of functional guilds (Altieri, 1999), and ecosystem services, especially biological pest control (Wilby and Thomas, 2002), This is predominantly apparent in industry-oriented plantation crop monocultures where chemical pesticides are the primary means of pest control (Sinu, 2011). Recently, because the general public negatively perceives the widespread application of pesticides, interest in biological pest control has grown rapidly coupled with governmental bans on several conventional pesticides (Meissle et al. , 2010). Too many pesticides in addition, pests continually evolve resistance. in experimental, natural, and managed habitats Birds are important predators of insect pests (Bretherton and Battisti, 2000), Yet, the practical value of as biocontrol agents of birds in agricultural systems is poorly understood and remains undervalued because it has been presumed that birds do not respond to insect pests in a density dependent manner and will not have a measurable impact on pest control (Mols and Visser, 2002). The higher the arthropod removal is expected to be strong (Johnson et al. , 2010). In agroecosystems natural vegetation is uncommon, the majority of birds depend cultivated areas such as plantations and paddy fields for survival. In agricultural belts Birds are generally small groups of opportunists which are able to exploit the changing environment caused by agricultural practice and are human commensals (McKay et al. , 1980). Dendrocitta vagabunda parvula (Passeriformes: Corvidae), Indian Treepie, is a wide spread arboreal noisy bird seen in coconut and areca palm plantation belts in south India. On successive visits suggests that most birds were defending territories, the fairly even dispersion of nests and the fact that non-breeders were usually found in similar places but presumably these were not of a very unbending nature. The subspecies P. b. burnesii (Blyth) occurs along the River Indus and its tributaries in Pakistan (Roberts, 1991). and adjacent north-west India (Muhammad et al. , 2010). Jerdon's Babbler in Pakistan it is known from a considerably wider area, spanning much of Punjab along the Indus, Jhelum, 
Chenab, Ravi and Sutlej rivers, and extending down the Indus into southern Sind. In the region People treat Indian Treepie as a bad sign and drive away, kill and destroy the nest and nestlings (Aarif et al. , 2011). As a pest of crops and predator on domestic animals there is no record about it Other than the brief notes on its feeding preference on flowers of red silk cotton (Bombax ceiba), Indian coral tree (Erythrina indica) and fruits of jackal jujube (Zacharias and Gaston, 1983), and cashew apple (Thirumurthy and Balashanmugam, 1987), predation of red palm weevil Rhychophorus ferrugineus (Krishnakumar and Sudha, 2002), cannibalism (Chhangani and Mohnot, 2004), and role in pollinating Bombax (Chhangani and Mohnot, 2004), about its feeding habit nothing is known. In the present effort, fed by the Indian Treepie information about the pest items, is still not documented it is ignored in many terms In Pakistan no documentation is seemed beside its distribution in different regions. So aim of present study is to find out the foraging behaviour of this common Treepie and role as enemy of pest of crops and fruites in district Haripur.

\section{MATERIALSAND METHODS}

This study was conducted in district Haripur. . Haripur is the main city of the Haripur District in Hazara, Khyber Pakhtunkhwa in Pakistan, with Swabi and Buner to the west, some $65 \mathrm{~km}$ north of Islamabad and $35 \mathrm{~km}$ south of Abbottabad. It is in a hilly plain area at an altitude of $520 \mathrm{~m}$. Having the $33.9946^{\circ} \mathrm{N}$, $72.9106^{\circ} \mathrm{E}$. With the pleasant weather and hilly areas with grasses and pine trees.

Treepie Food items were determined by direct focal observation method (Altman, 1981), analysis of gut content (Altman et al. , 1974) and analysis of faecal matter. Birds were monitored from a distance of 5$10 \mathrm{~m}$ with a binocular by hiding behind trees and a telescope $(20 \mathrm{x})$; for 15 days/month at the rate of 1 hr/day, during 2018 period. Altogether 130 visits were made. Spotted from study site Gut contents of four dead birds were analyzed. Ten fresh faecal matter samples collected from the ground was rinsed in water and the materials were sorted using a brush and magnifying glass. Collected items were identified up to order/family/genus/species level. Food items were quantified according to their frequency of occurrence (F.O). The presenc of an item, despite the number of individuals containing in the sample was taken as frequency of occurence (F.O) (Rocha et al., 2008). Percentage of occurrence (P.O) was quantified by counting all occurrences of an item to estimate the minimal number of preyed individuals. Since the faecal matter analysis solely emphasised the undigested hard tissues of the consumed items, the P.O was not considered.

\section{RESULTS}

Analysis of Diet (gut content analysis, direct focal observation, and analysis of faecal matter) revealed that the prey items consist of 14 pests present on coconut fruites and wheat and maize crops and plantation which include snail's vertebrates and insects. Insects were 64 percent. It includes leaf-eating caterpillar (Opisina arenosella), larvae of various other insect groups and a major pest of banana, banana stem weevil (Odoiporus longicollis) (Sahayaraj and Kombiah, 2009). Comparison with similar data for Carrion Crows Shows that treepies spend much more time feeding on marginal land, especially rough grassland alongside. It was also apparent that Treepie regularly feed closer to thick cover than do Carrion Crows, and spend more time feeding in long grass and tall cereal crops which is in agreement with our findings. Earwigs that are in abundance on maize crop, one chrysomelid beetle and orthoptera were found to be among the major food items., black-headed munia (Lonchura Malacca) nestlings of squirrel (Funambulus sp.), house rat (Rattus rattus) were among the vertebrate pests and eggs of black-headed munia blue rock pigeon (Columba livia) that is kept in my own house were found. he most accounted invertebrate groups were grasshoppers, earwigs, insect larvae, red palm weevil and cockroach According to direct focal observation method.

Table.1 different analysis for the tree piee.

\begin{tabular}{llll}
\hline Common name & Order/Family/Genus/Species & Gut content analysis & Gut content analysis \\
\hline & & frequency of occurance & occurance \% \\
Earwig & Forficulidae & 3 & 75 \\
Grasshopper & Orthoptera & 2 & 50 \\
Insect larvae & Various groups & 42 & 10050
\end{tabular}




\begin{tabular}{llll}
\hline Common name & Order/Family/Genus/Species & Gut content analysis & Gut content analysis \\
\hline Cockroach & Periplanetta sp & 4 & 100 \\
Snail & Pulmonata & 4 & 100 \\
Beetle -3 & Unidentified Curculionidae & 2 & 50 \\
Black-headed Munia (nestling) & Lonchura malacca & 3 & 75 \\
House rat & Rattus rattus & 0 & 0 \\
Blue Rock Pigeon (nestling) & Columba livia & 3 & 75 \\
Squirrel (nestling) & Funambulus sp & 2 & 50 \\
Leaf-eating caterpillar & 42 & 10050 & 6 \\
& 42 & & 6 \\
\hline
\end{tabular}

\section{DISCUSSION}

Most agricultural and natural landscapes have several pest species that rapidly increase in population size and by causing significant ecological and economic damage. Since natural vegetation is uncommon in agroecosystems, the majority of birds depend cultivated areas such as plantation and paddy fields for survival. Birds in agricultural belts are generally small groups of opportunists which are able to exploit the changing environment caused by agricultural practice and are human commensals. Farmers drive away roosting birds from plantations by using fireworks due to the damage caused by communally roosting birds to the coconut flowers and fronds. Harvesters destroy the nest and nestlings of the breeding birds found in the tree during fruites collection. Usually very less amount of pesticide is using tree pests and also for different crops so it is an ecofriendly system which indirectly conserve a habitat of resident bird fauna. In villages awareness about the role of this Treepie in agriculture to farmers and villagers will helps to conserve these associated birds. To be potential biocontrol agents of agricultural pests, birds need to have a density dependent response to pest outbreaks. A numerical response can be achieved either by higher species richness of insectivorous birds or density of an important insectivorous species. Nevertheless, birds generally contribute to maintain low abundance levels of insect pests and have no impact left during out breaking conditions. Insects, in order to avoid predators, use certain simple an On the beneficial role of tree pie from district Haripur will be helpful for further studies as a natural predator of numerous major pests of the trees and cultivated crops that remained unnoticed. Its ability to reach up to the bottom side of front trees which is not foraged by any other bird elevates its position as a special niche predator in trees. In addition to the hang feeding, shake and wait catch method of food capturing (Basheer et al. , 2010) is in agreement with the present finding. For all these reasons, biological control is preferable wherever possible. However, biological control is a complex matter and the controlling agent cannot always be found locally (Buchholz, 1999). Capacity of Treepie to feed upon adult and larvae of many insect pests on the lower surface of the leaflets indicates its utility as a natural predator and biological control agent. Among the insect pests consumed(Sadakathulla, 1991). The leaf-eating caterpillar, Opisina arenosella Walker is the most important lepidopteran pest of coconut palm in South Asia (Sadakathulla, 1991).While foraging, Indian Treepie tears open the silken webs on the leaflets and consume the caterpillars hiding beneath. Phytophagous chrysomelidae includes many established and potential agricultural pests and studies on host plants and ecology of Indian chrysomelids are highly inadequate (Kalaichelvan et al. , 2005). Chrysomelid beetles found on the tender leaflets of coconut and areca palm fronds and fed by Indian Treepi. Cultivation suffer severe damage mainly by rats (Rattus sp.) (Parshad, 1999a). Consumption of nestlings of pests like house rat and squirrel damaging (Parshad, 1999b), by Indian Treepie appears to be primarily due to their nesting site on the trees also reported in present study that the tree pie was found to be predator on the nestling of these species. Earwigs (Forficulidae) threaten the insect pollinators attempting to visit the female flowers (Geiser et al. , 2000), hence their predation by Indian Treepie enhances the pollination of the trees. It is essential that farmers should be made aware of the beneficial role of these birds as a natural predator of the several major pests of the trees crops and that the Indian Treepie is not a pest of any major food items or crops in the region. To the disappearance of this beneficial bird from the agricultural fields and it requires spreading awareness about its status as a beneficial bird among the farming community. 


\section{Competing Interests}

Authors have no competing interest

\section{Author Contributions}

All authors equally contributed in manuscript

\section{Funding information}

No funding received by any source

\section{Acknowledgments}

I would like to aknowledge my co authors

\section{Data Availability Statement}

The authors confirm that the data supporting the findings of this study are available within the article its supplementary materials

Aarif, K., Babu, S. and Basheer, M. (2011) Arrival and Departure of Pallas's Gulls Larus ichthyaetus in Kerala, southern India.Journal homepage: www. wesca. net, 6(2).

Altieri, M. A. (1999) The ecological role of biodiversity in agroecosystems. Invertebrate Biodiversity as Bioindicators of Sustainable Landscapes. Elsevier.

Altman, E. I., Margaine, M., Schlosser, M. and Vernimmen, P. (1974) Financial and statistical analysis for commercial loan evaluation: a French experience. Journal of Financial and Quantitative Analysis, 9(2): 195-211.

Altman, J. (1981) Functional organisation of insect ganglia.Neurobiology of invertebrates. Elsevier.

Basheer, C., Lee, J., Pedersen-Bjergaard, S., Rasmussen, K. E. and Lee, H. K. (2010) Simultaneous extraction of acidic and basic drugs at neutral sample $\mathrm{pH}$ : a novel electro-mediated microextraction approach.Journal of Chromatography a, 1217(43): 6661-6667.

Bretherton, C. S. and Battisti, D. S. (2000) An interpretation of the results from atmospheric general circulation models forced by the time history of the observed sea surface temperature distribution. Geophysical Research Letters, 27(6): 767-770.

Buchholz, E. S. (1999) Alonetime: A developmental need with prenatal origins. INTERNATIONAL JOURNAL OF PRENATAL AND PERINATAL PSYCHOLOGY AND MEDICINE, 11: 5-18.

Chhangani, A. and Mohnot, S. (2004) Crop raid by hanuman langur Semnopithecus entellus in and around aravallis (India) and its management. Primate report : 35-48.

Geiser, F., Holloway, J. C., Körtner, G., Maddocks, T. A., Turbill, C. and Brigham, R. M. (2000) Do patterns of torpor differ between free-ranging and captive mammals and birds? Life in the cold.Springer.

Johnson, M., Kellermann, J. and Stercho, A. (2010) Pest reduction services by birds in shade and sun coffee in Jamaica. Animal conservation, 13(2): 140-147.

Kalaichelvan, T., Verma, K. and Sharma, B. (2005) Checklist of leaf beetles (Coleoptera: Chrysomelidae) of Bhilai-Durg. Zoos' Print Journal, 20(4): 1838-1842.

Krishnakumar, R. and Sudha, G. (2002) Indian tree pie Dendrocitta vagabunda parvula (Whistler and Kinnear)(Corvidae). A predatory bird of red palm weevil Rhynchophorus ferrugineus (Oliv.). Insect Environment, $8(3): 133$.

McKay, G., Otterburn, M. and Sweeney, A. (1980) The removal of colour from effluent using various adsorbents - III. Silica: Rate processes. Water Research, 14(1): 15-20. 
Meissle, M., Mouron, P., Musa, T., Bigler, F., Pons, X., Vasileiadis, V., Otto, S., Antichi, D., Kiss, J. and Pálinkás, Z. (2010) Pests, pesticide use and alternative options in European maize production: current status and future prospects. Journal of Applied Entomology, 134(5): 357-375.

Mols, C. M. and Visser, M. E. (2002) Great tits can reduce caterpillar damage in apple orchards. Journal of applied ecology,39(6): 888-899.

Muhammad, S., Khan, A. A., Babar, M., Riaz, M., Akhtar, N. and Khaliq, I. (2010) Population genetic structure of Rufous-Vented Prinia (Prinia burnesii) in Pakistan. African Journal of Biotechnology,9(53): 9077-9081.

Parshad, R. (1999a) Effects of selenium toxicity on oestrous cyclicity, ovarian follicles, ovulation and foetal survival in rats.

Parshad, V. (1999b) Rodent control in India. Integrated Pest Management Reviews, 4(2): 97-126.

Roberts, T. J. (1991) The Birds of Pakistan: In 2 Volumes. Regional Studies and Non-passeriformes, Oxford University Press Karachi, Pakistan.

Sadakathulla, S. (1991) Management of red palm weevil, Rhynchophorus ferrugineus. F. in coconut plantations. Planter (Malaysia).

Sahayaraj, K. and Kombiah, P. (2009) Olfactory responses of the banana weevil, Odoiporus longicollis (Olivier)(Coleoptera: Curculionidae) against pseudostem and its crude extract. Journal of Biopesticides, $2(2): 173-176$.

Sinu, P. A. (2011) Avian pest control in tea plantations of sub-Himalayan plains of Northeast India: Mixedspecies foraging flock matters. Biological Control, 58(3): 362-366.

Thirumurthy, S. and Balashanmugam, P. (1987) Birds associated with fruiting cashew trees. The Cashew, $1(2): 18$.

Wilby, A. and Thomas, M. B. (2002) Natural enemy diversity and pest control: patterns of pest emergence with agricultural intensification.Ecology Letters, 5(3): 353-360.

Zacharias, V. and Gaston, A. (1983) Breeding seasons of birds at Calicut, Southwest India. Ibis, 125(3): 407-412. 